\title{
Critical points and magnitude of impacts on the packing line: effect on ripening and quality of 'Packham's Triumph' pears
}

\section{Pontos críticos e magnitude de impacto na linha de beneficiamento: efeito no amadurecimento e qualidade de peras 'Packham's Triumph'}

\author{
Josiane Pasini ${ }^{1}$; Lucimara Rogéria Antoniolli2*; Renar João Bender ${ }^{3}$
}

\begin{abstract}
Pears have a very sensitive epidermis and are prone to signal mechanical blemishes, which result in reduced visual quality and low consumer acceptance. The objective of this work was to identify critical points and the magnitude of impact forces on a packing line at a commercial packinghouse. The effect of injuries on ripening and quality of 'Packham's Triumph' pears was also evaluated after cold storage. The packing line was scrutinized on its transfer points, fruit drop heights and cushioning overlays, which allowed to acquire the maximum accelerations on each spot. The maximum acceleration forces were reproduced in the lab with 'Packham's Triumph' pears to evaluate the effects on fruit quality after cold storage. Four critical points were noticed on the packing line: at the transfer from the conveyor belt to the lifting rollers, at the transfer from the lifting rollers to the washing ramp with rotatory brushes, at the entrance to the singulator at the end of the conveyor belt and at the drop from the sizer to the packing stalls. Ripening of 'Packham's Triumph' pears invariably came about during cold storage, and independently of the imposed impacts. The impacts under the circumstances of the test did not affect the quality of 'Packham's Triumph' pears kept for up to 120 days at cold storage followed by five days at room temperature.
\end{abstract}

Key words: Pyrus communis L. G forces. Mechanical injuries. Packing line.

\section{Resumo}

Peras apresentam epiderme muito sensível e são propensas aos sinais de danos mecânicos, que resultam em qualidade visual reduzida e baixa aceitação dos consumidores. O objetivo deste trabalho foi identificar os pontos críticos e a magnitude dos impactos em uma linha de beneficiamento e classificação de frutas em uma casa de embalagem comercial. Também foi avaliado o efeito das lesões sobre o amadurecimento e a qualidade de peras 'Packham's Triumph', mantidas sob refrigeração. A linha de beneficiamento e classificação foi avaliada quanto aos pontos de transferência, altura de queda das frutas e material de superfície de queda, permitindo obter a aceleração máxima em cada ponto. Os valores de aceleração máxima foram reproduzidos em laboratório com peras 'Packham's Triumph', para avaliar seus efeitos na qualidade das frutas após armazenamento refrigerado. Quatro pontos críticos foram observados na linha de beneficiamento e classificação: da esteira rolante para o elevador de roletes,

${ }^{1}$ Prof. M.e, Instituto Federal de Educação, Ciência e Tecnologia Rio Grande do Sul - Campus Bento Gonçalves, IFRS, Bento Gonçalves, RS, Brasil. E-mail: josiane.pasini@bento.ifrs.edu.br

${ }^{2}$ Pesquisadora, Dra ${ }^{\text {a }}$ Empresa Brasileira de Pesquisa Agropecuária, EMBRAPA, Centro Nacional de Pesquisa Uva e Vinho, Bento Gonçalves, RS, Brasil. E-mail: lucimara.antoniolli@embrapa.br

${ }^{3}$ Prof. Dr., Departamento de Horticultura e Silvicultura, Faculdade de Agronomia, Universidade Federal do Rio Grande do Sul, UFRGS, Porto Alegre, RS, Brasil. E-mail: rjbe@ufrgs.br

* Author for correspondence 
do elevador de roletes para a rampa de lavagem com escovas rotativas, na entrada do singulador, ao final da esteira rolante, e na queda do calibrador para a mesa de embalagem. Durante o armazenamento refrigerado ocorreu o amadurecimento de peras 'Packham's Triumph', independente do tratamento de dano mecânico por impacto aplicado. Os danos mecânicos por impacto, nas condições testadas, não afetam a qualidade de peras 'Packham's Triumph' mantidas por até 120 dias de refrigeração, seguidos por cinco dias em temperatura ambiente.

Palavras-chave: Pyrus communis L. Força G. Injúria mecânica. Linha de classificação e beneficiamento.

\section{Introduction}

Pears (Pyrus communis L.) are imported into Brazil in high volumes. According to Fioravanço and Oliveira (2014), in 2012, about 224 thousand tons of pears were imported. Brazil produces only approximately $10 \%$ of its consumption of pears, which indicates the high growth potential for that species. Yet, at numerous occasions, yields have been discouraging. Pears present an especially sensitive epidermis and are prone to signal mechanical blemishes, which result in reduced visual quality at retailers diminishing consumer acceptance.

Mechanical injuries derive from several causes: compression forces, impacts and frictions occur at harvest, transport, at the packinghouse and as well during transport to the market (SEGATORI, 2006).

Impacts befall when a fruit collides against a rigid surface. The damages, more often than not, are visible on the fruit epidermis. Breakups might or might not occur. However, watery and translucent blemishes leading to tissue softening come about (SANCHES et al., 2008). In addition to visual quality losses, mechanical injuries speed up fruit metabolism, anticipate senescence and reduce postharvest shelf life. Mechanical injuries inflicted by impacts stimulate respiration rates (AGAR; MITCHAM, 2000) and decrease flesh firmness in pears (SINOBAS et al., 1991), reduce titratable acidity (HENDGES et al., 2011) and intensify browning of damaged tissues in apples (MONTERO, 2010).
On fruit packing lines, the main factors favoring mechanical injuries by impacts are the height differences along the line of fruit movement, the existence of rigid surfaces along the sorting unit and the high speed of fruit movement along the line. The more rigid the surfaces (metal, wood or plastic) the higher the incident energy upon the fruit and, consequently, the damages will be more severe. Smooth surfaces tend to absorb part of the generated energy by the falling fruit because of larger contact areas scattering the overall impact (SEGATORI, 2006).

The evaluation of the magnitude of impacts at transfer points on a fruit-sorting machine is feasible to be accomplished with the use of an instrumented sphere (Techmark, Inc. Lansing, EUA). The sphere is made of a rigid cover, with a format and dimensions of a fruit. The sphere contains in its inside impact sensors. The instrumented sphere (IS) has already been tested on apple packing lines (BROWN et al., 1990; ANTONIOLLI et al., 2009), at sorting of tomatoes (FERREIRA et al., 2006a) and citrus (FERREIRA et al., 2006b). The levels of impacts are determined as a result of maximum acceleration (MA) and motion changes $\left(\mathrm{m} \cdot \mathrm{s}^{-1}\right)$ (ANTONIOLLI; FERREIRA, 2010).

Bearing in mind that background, the present work intended to pinpoint critical points at a pear packing line and the magnitude of impacts on a commercial packing line and to evaluate the effects of injuries by impacts on the ripening and quality of 'Packham's Triumph' pears stored under refrigeration. 


\section{Materials and Methods}

Identification of critical points and impact magnitudes on a commercial fruit packing line

Evaluations were done in a commercial packinghouse located in Farroupilha, Rio Grande do Sul, the southernmost state in Brazil. The packing line is used without any special adaptations for different fruit species amongst those, pears, apples and peaches.

At the start, the sorting machine was thoroughly inspected predominantly at its transfer points. After that, the height differences and, likewise, the cushioning of surfaces at drop stations and the mechanisms for decelerations such as curtains and ramps were determined. Maximum acceleration $(\mathrm{G}$ $=9.81 \mathrm{~m} \cdot \mathrm{s}^{-2}$ ) at each transfer location of the packing line was determined taken in account the heights and the padding of the surfaces by the equations previously defined (ANTONIOLLI et al., 2009).

The authors obtained these equations releasing an IS of $70 \mathrm{~mm}$ diameter and mass of $165 \mathrm{~g}$ (Techmark, Inc. Lansing, EUA) from heights ranging from one to $42 \mathrm{~cm}$ at $3 \mathrm{~min}$ intervals onto two different surfaces: metal or an $8 \mathrm{~mm}$ thick rubber padding (Ingeniería Prodol S/A).

For a drop onto a metal surface, the equation determined by the authors is $\mathrm{G}=-0.1909 \mathrm{x}^{2}+$ $16.989 x+72.585$ and for the drop onto a rubber padding $\mathrm{G}=4.8391 \mathrm{x}+7.8026$. The variable ' $\mathrm{x}$ ' represents the falling height.

Effects of mechanical injuries by impacts on ripening and quality of 'Packham's Triumph' pears

'Packham's Triumph' pears were harvested from a commercial orchard located in São Francisco de Paula, Rio Grande do Sul, Brazil. At harvest, the size and epidermal color of the fruit were determinant of maturity stage. After 15 days at $0 \pm 0.5^{\circ} \mathrm{C}$ plus $90 \pm$ $5 \%$ UR to even out ripening the pears were retrieved from storage and maintained for approximately four hours at $20 \pm 2{ }^{\circ} \mathrm{C}$ prior to submitting to the impact treatments.
Impact treatments were applied using a device connected to a vacuum pump, which provided the fruit adhesion by suction and its fall when the vacuum pump is turned off (MAGALHÃES et al., 2007). The heights were adjusted so that all fruit, independently of its diameter, would drop from exactly the same height. Chalk powder was spread on the impact surface to indicate the exact spot of impact, which was subsequently delimited with a permanent marker.

Four impact treatments were applied: control (without impact), drops from heights of $6.5 \mathrm{~cm}$ or $15 \mathrm{~cm}$ onto an $8 \mathrm{~mm}$ thick rubber padding (Ingeniería Prodol S/A) and drop from a $6.5 \mathrm{~cm}$ height onto a metal surface. After treatment application, the pears were placed on molded pulp trays in plastic boxes and transferred to cold storage units at $0 \pm 0.5^{\circ} \mathrm{C}$ e $90 \pm 5 \%$ UR.

The pears were evaluated after five, 30, 60, 90 or 120 days of cold storage plus five more days at room temperature $\left(24 \pm 1{ }^{\circ} \mathrm{C}\right)$ for quality traits: fresh weight losses, epidermal color at injured and not injured areas, flesh firmness, soluble solids and titratable acidity. Immediately after the impact treatments, the integrity of membranes and respiration rates were determined.

To determine respiration rates, three pears from each treatment were arranged in $3 \mathrm{~L}$ glass jars to sample for headspace $\mathrm{CO}_{2}$ production expressed as $\mathrm{mL} \mathrm{CO} \mathrm{Kg}^{-1} \mathrm{~h}^{-1}$. After one, three, five and 24 hours at room temperature, $1.0 \mathrm{~mL}$ air samples were retrieved and injected into Shimadzu gas chromatograph (model GC-2014) equipped with $1 / 8$ " packed column at $70{ }^{\circ} \mathrm{C}$ using $\mathrm{N}_{2}$ as carrier gas $\left(26 \mathrm{~mL} \mathrm{~min}^{-1}\right)$.

Membrane integrity was determined using nine discs ( $2 \mathrm{~mm}$ thick and $9 \mathrm{~mm}$ diameter) of either the injured areas or healthy tissues that were retrieved and washed in distilled water and immersed in a 0.4M mannitol solution (FELÍCIO et al., 2006). Electrolyte leakage was determined on a Digimed (model DM-32) conductivimeter immediately after 
retrieval, after three hours stirring at $30^{\circ} \mathrm{C}$ and after a freeze-thawing process. Results are expressed in $\mu \mathrm{S} \cdot \mathrm{cm}^{-1}$ on time zero and as percent of leached electrolytes after three and 24 hours.

Flesh firmness was determined, after removal of part of the epidermis, with a Mc Cornick, (model FT327) hand penetrometer equipped with an $8 \mathrm{~mm}$ Magness-Taylor probe. Results were expressed in Newton (N). Soluble solids ( ${ }^{\circ}$ Brix) were determined on a digital refractometer (Atago, model PR101 Pallet). The readings were corrected to $20{ }^{\circ} \mathrm{C}$. Titratable acidity (percentage of malic acid) was determined by titration of $10 \mathrm{~mL}$ homogenized juice with $0.1 \mathrm{M} \mathrm{NaOH}$ up to $\mathrm{pH} 8.1$ on a Marconi (model PA 200) pH meter (AOAC, $\left.n^{\circ} 942.15,2002\right)$.

Peel color measurements were performed with a Konica Minolta (model CM-2500d) color meter in the $L^{*} a^{*} b^{*}$ system. Two measurements were taken on healthy and as well of injured areas.

The experiments were carried on a completely randomized design, four replicates/treatment and experimental units of five fruit each. For electrolyte leakage, determinations the experimental units consisted of three fruit. Respiration rates were taken from three replicates of three pears/ replicate.

Data were submitted to analysis of variance and averages compared by Tukey $(p<0.05)$. Percentage data were transformed according to the formula $\operatorname{arcsen} \sqrt{ } \mathrm{x} / 100$.

\section{Results and Discussion}

On the packing line nine spots were identified at which different heights and cushioning materials were in place (Table 1).

Table 1. Transfer points observed in the commercial line for fruit processing and classification with their respective variations in height and impact surfaces.

\begin{tabular}{ccccc}
\hline $\begin{array}{c}\text { Transfer } \\
\text { points }\end{array}$ & Starting point & Transfer point & Height $(\mathrm{cm})$ & Impact surface \\
\hline 1 & Bin unloading & Conveyor belt & Variable & Canvas \\
2 & Conveyor belt & Elevator with rollers & 6.5 & Rubber padding \\
3 & Elevator with rollers & $\begin{array}{c}\text { Washing unit with } \\
\text { rotating brushes }\end{array}$ & 5.0 & Metal \\
& Wash unit with rotating & Selection table with & 4.0 & Rubber padding \\
4 & brushes & rotating rollers & & Rubber padding with \\
& Selection table with rotating & Conveyor belt & 10.4 & plastic curtain \\
5 & rollers & Rubber padding \\
6 & Conveyor belt & Entry to the singler & 4.8 & Metal \\
6.1 & Conveyor belt & Singler & 6.5 & Roller (hard plastic) \\
7 & Singler & Sizer & 6.0 & Rubber padding \\
\hline
\end{tabular}

The greatest drop heights were identified at transfer from the sizer to the box-filling table $(15.2 \mathrm{~cm})$ and at the inspection table with rollers to the conveyor belt $(10.4 \mathrm{~cm})$. The smallest drop height was identified at the station of drench washing with rotating brushes $(4.0 \mathrm{~cm})$. The paddings at these surfaces were either rubber or metal (Table 2). Maximum accelerations occur at the transfer point to metal surfaces where the highest drop height yielded the highest acceleration. Rubber paddings yielded the lowest acceleration values. Transfer points two and six with distinct paddings do present highest drop 
height. Maximum acceleration on a metal surface was four times higher in comparison to rubbery padding. In tomatoes, the highest acceleration was determined by drop heights of 10 or $30 \mathrm{~cm}$ on rigid surfaces (MAGALHÃES et al., 2007). During the impact, smooth paddings dissipate the energy creating a bigger contact surface reducing the amount of incident energy on the fruit (GOMILLA, 2007). In contrast, rigid surfaces do not have the capacity do deform and the energy is completely absorbed by the fruit. Impacts against abrasive surfaces like concrete or metal might be possible causes of damages to fruit (MILLER; WAGNER, 1991). The authors evaluated with assistance of an instrumented sphere the magnitude of impacts on a packing line of oranges and concluded that $80 \%$ of the impacts varied from 25 and $150 \mathrm{G}$ and were originated from drops onto metal rigid surfaces or covered with only a thin rubber layer.

Table 2. Maximum acceleration $(\mathrm{G})$ at transfer points on a commercial processing and classification unit.

\begin{tabular}{cclc}
\hline Transfer point & Height $(\mathrm{cm})$ & \multicolumn{1}{c}{ Material impact surface } & Maximum acceleration $(\mathrm{G})$ \\
\hline 2 & 6.5 & Rubber padding & 39.25 \\
3 & 5.0 & Metallic & 152.75 \\
4 & 4.0 & Rubber padding & 27.16 \\
5 & 10.4 & Rubber padding & - \\
6 & 4.8 & Rubber padding & 31.03 \\
$6 \mathrm{a}$ & 6.5 & Metallic & 174.95 \\
8 & 15.2 & Rubber padding & 81.35 \\
\hline
\end{tabular}

Acceleration values ranging in between 30 and $50 \mathrm{G}$ on rigid surfaces may cause visible injuries on apples, i. e., areas bigger than $50 \mathrm{~mm}^{2}$ (SEGATORI, 2006). Acceleration values in between 50 and $80 \mathrm{G}$ are to be considered of high risk while values below $25 \mathrm{G}$ normally do not cause mechanical injuries on fruit.

The transfer point number 2 (transfer from the conveyor belt to the elevator with rollers) even though with a maximum acceleration below 50 $\mathrm{G}$, had visible signs of deterioration of its rubbery ramp. The stiffness, the deterioration or collapse of the material reduces de capability to absorb impacts, being necessary check constantly and replace when necessary (GOMILLA, 2007).

For the replication of mechanical injuries and the evaluation of their effects on ripening and quality of pears different drop heights determined at the packing line were selected. The highest drop height on a rubber padding determined at the packing line was $15 \mathrm{~cm}$. That drop height resulted in an acceleration of $81.35 \mathrm{G}$. The drops onto a metal or rubber surface from a height of $6.5 \mathrm{~cm}$ resulted in accelerations of $174.95 \mathrm{G}$ and $39.25 \mathrm{G}$, respectively.

The damages caused by impacts were not visible on the outside of the evaluated pears at the end of the refrigerated storage periods followed by five more days at room temperature. In the mesocarp, the lesions were not visible after five days of treatment application and after 30 days of refrigerated storage followed by five more days at room temperature (Figure 1).

However, after 60 days of refrigerated storage followed by five more days at room temperature, the wounds became visible, mainly on fruits, which had been dropped from a height of $6.5 \mathrm{~cm}$ onto a metal surface. After 90 days of refrigerated storage and five more days at room temperature, $40 \%$ of the fruit of that same treatment presented evident injuries. That percentage is significantly higher in comparison to all the other treatments. 
Figure 1. Percentages of 'Packham's Triumph' pears injured by different impact forces and stored at $0 \pm 0.5{ }^{\circ} \mathrm{C}$ e 90 $\pm 5 \%$ UR for up to 120 days and followed for five more days at room temperature $\left(24 \pm 2{ }^{\circ} \mathrm{C}\right)$. Averages followed by the same letter do not differ by Tukey test $(p<0.05) .{ }^{*}$ The fruit from the other treatments had no signs of injuries.

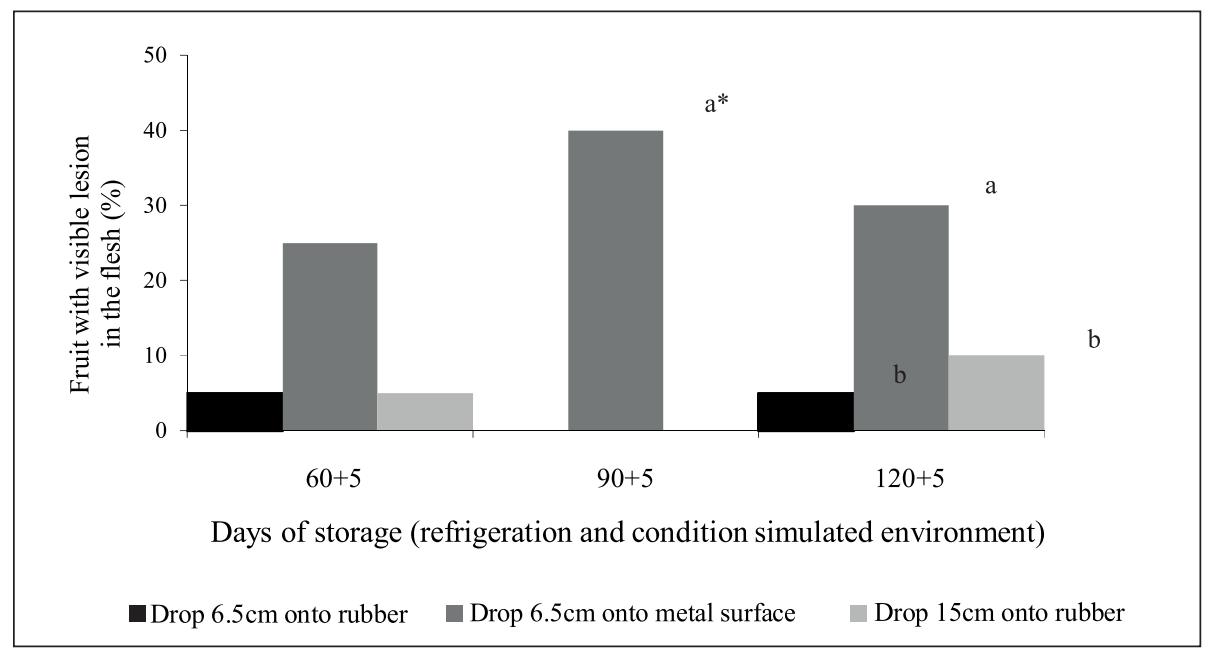

After 120 days of storage and as well followed by five days at room temperature, the drop from a height of $6.5 \mathrm{~cm}$ onto a rubbery padding resulted in the lowest percentage of noticeable injuries. On tomatoes, an increase of $31 \%$ was observed in internal bruises after the fruit had been submitted to drops of $30 \mathrm{~cm}$ onto a metallic surface in comparison to drops from the same height onto a foam-covered surface (MAGALHÃES; FERREIRA, 2006). Occurrence of impacts may not always result in visible bruises on the epidermis, nonetheless the mesocarp will undergo changes in response to the inflicted energy. These internal changes might result from the activation of defense mechanisms such as buildup of phenolic compounds (MORETTI, 2007). In that process, evolves the deposit of lignin and other polymerized carbohydrates in the cell walls.

The severity of mechanical injuries by impacts do not affect respiratory activity of 'Packham's Triumph' pears (Figure 2). After one hour of the impact treatment, the average respiration rate was $7.5 \mathrm{~mL} \mathrm{CO} \mathrm{kg}^{-1} \mathrm{~h}^{-1}$. After three hours, the rates increased up to $11.6 \mathrm{CO}_{2} \mathrm{~kg}^{-1} \mathrm{~h}^{-1}$ and after five hours the rates were $17.4 \mathrm{~mL} \mathrm{CO}_{2} \mathrm{~kg}^{-1} \mathrm{~h}^{-1}$. After 24 hours, the respiration had dropped to $13.7 \mathrm{~mL} \mathrm{CO}_{2} \mathrm{~kg}^{-1} \mathrm{~h}^{-1}$.

Figure 2. Respiration rates of 'Packham's Triumph' pears submitted to impacts and maintained for 24 hours $20 \pm 2$ ${ }^{\circ} \mathrm{C}$. Vertical bars indicate standard deviation $(\mathrm{n}=3)$.

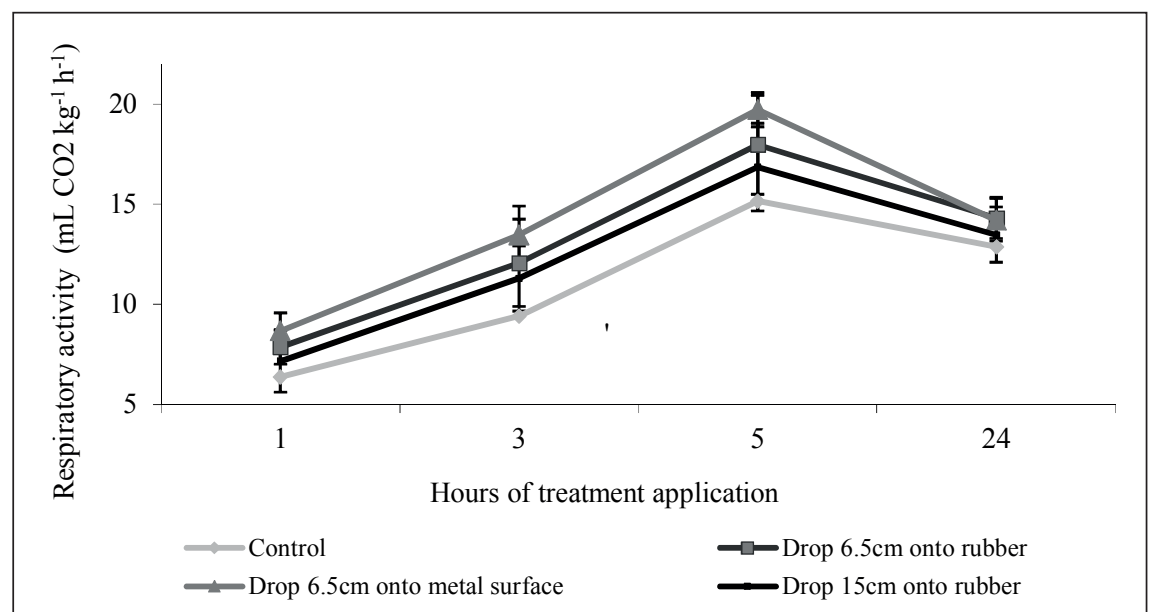


Respiration rates determined in the present work were similar to the rates determined in 'Bartlett' pears, which underwent several processing steps at a packinghouse (AGAR; MITCHAM, 2000).

After 24 hours of the box filling process and keeping at $20{ }^{\circ} \mathrm{C}$ a respiration rate of $10 \mathrm{~mL} \mathrm{CO}_{2}$ $\mathrm{kg}^{-1} \mathrm{~h}^{-1}$ was noticed and, as well, that there were no differences in respiration rates amongst the various processing steps. A similar approach did not detect significant differences in respiration rates of apples submitted to drops from $0.2 \mathrm{~m}$ heights (STEFFENS et al., 2008).
At harvest time, the pears had an average flesh firmness value of $74.8 \mathrm{~N}$. After 15 days of cold storage following impact treatments firmness averages were about $72.8 \mathrm{~N}$. Independently of the severity of the mechanical injury the pears had endured, the behavior of the variable fits a second order model (Figure 3).

After five days of treatment applications the pears still were firm. Flesh firmness was about $70 \mathrm{~N}$. Firmness values decreased to $10.0 \mathrm{~N}$ after 90 days of cold storage followed by five more days at room temperature.

Figure 3. Flesh firmness $(\mathrm{N})$ of 'Packham's Triumph' pears submitted to different impact treatments after storage $0 \pm$ $0.5^{\circ} \mathrm{C}$ and $90 \pm 5 \%$ UR up to 120 days followed by five more days at room temperature at $24 \pm 2{ }^{\circ} \mathrm{C}$.

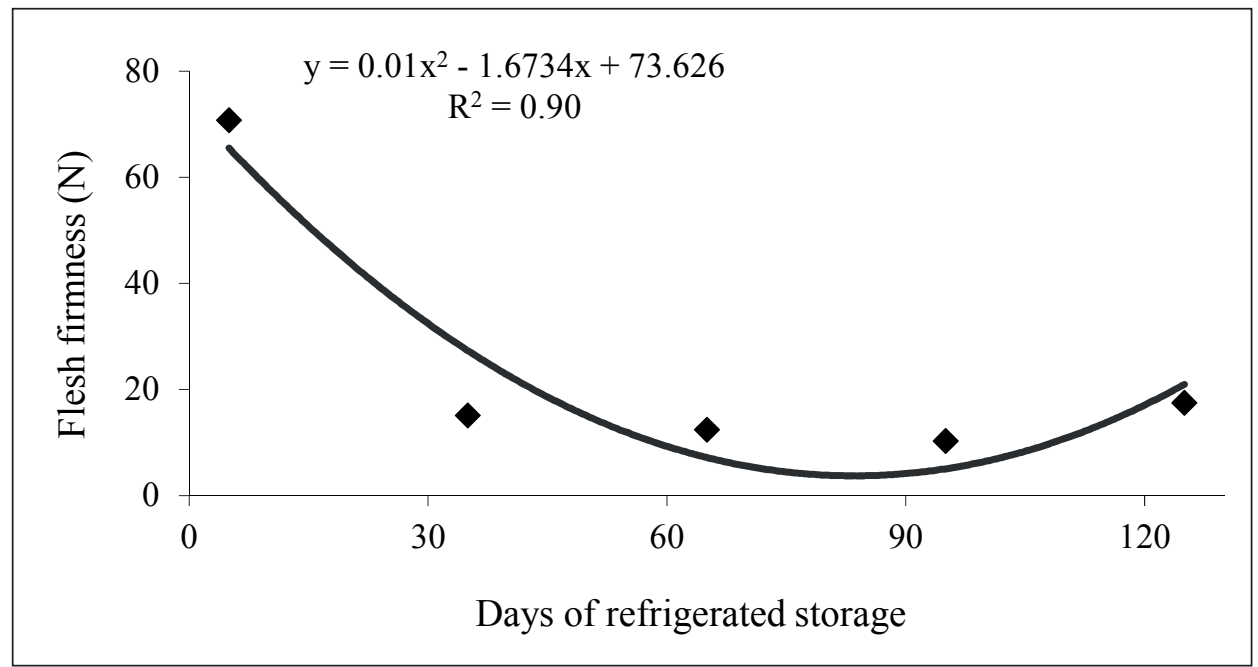

Pears are at its best for consumption concerning texture and juiciness when firmness values are between 18.0 and 22.0 N (KAPPEL et al., 1995). Assenting with that observation and using the equation of figure 3 , the pears of the present work reached its best eating quality after 41 to 46 days after treatment application. On the evaluations after 60 and 90 days of cold storage plus five more days at room temperature, flesh firmness values were 9.22 and $4.02 \mathrm{~N}$, respectively. Even though the pears were way below the recommended flesh firmness values, the fruit were of acceptable appearance and suitable for consumption.
According to that same equation, flesh firmness of 'Packham's Triumph' pears continued to decline up to 86 days $(3.7 \mathrm{~N})$ of cold storage. After that period of storage, an increment in fruit firmness was determined up to $120^{\text {th }}$ day. That increase in firmness values is attributable to a more elastic fruit flesh in response to losses in turgidity of the tissues and therefore a little more resistant to the penetrometric test.

Average values of soluble solids were in the order of $9.8^{\circ}$ Brix at harvest and at the end of the storage period were about $11.3{ }^{\circ}$ Brix. Alike flesh firmness values, the averages of soluble solids fit a second order model (Figure 4). 
Figure 4. Soluble solids contents ( $\left.{ }^{\circ} \mathrm{Brix}\right)$ of 'Packham's Triumph' pears submitted to impact treatments and stored for up to 120 days at $0 \pm 0.5^{\circ} \mathrm{C}$ and $90 \pm 5 \%$ UR followed by five more days at room temperature $\left(24 \pm 2{ }^{\circ} \mathrm{C}\right)$.

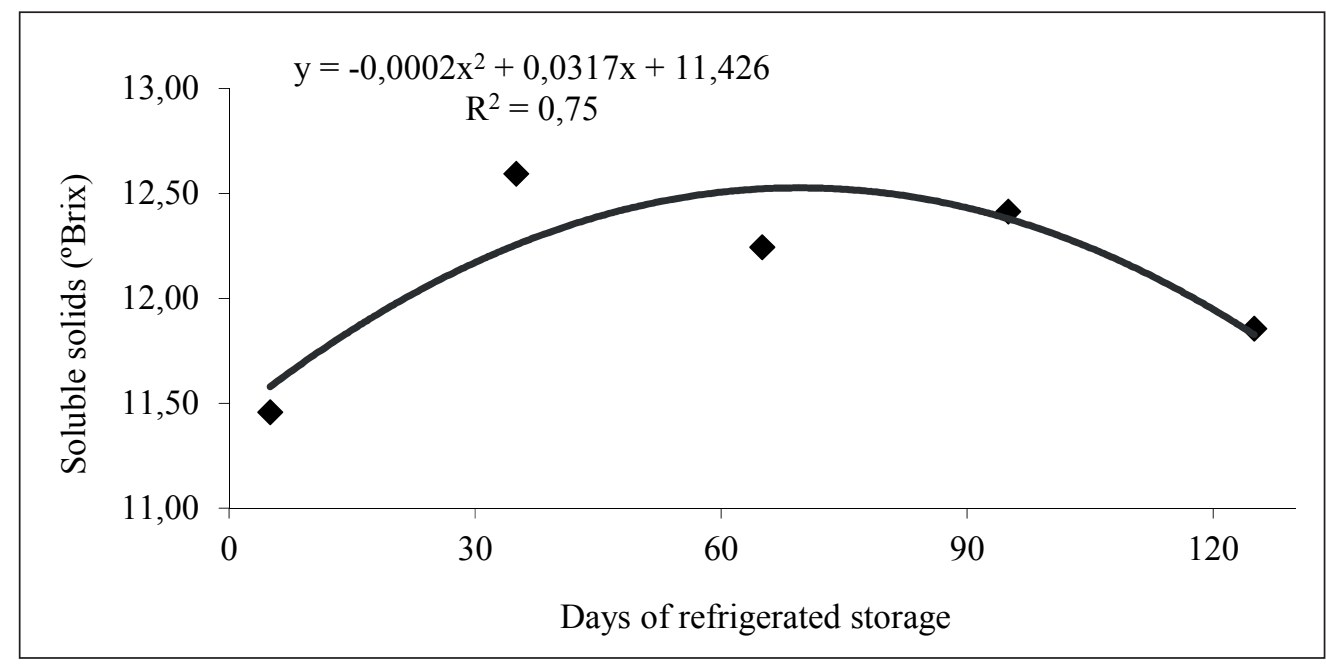

An increase in soluble solids occurs up to 60 days of cold storage. From that period onwards, a slight decrease was identified. Pears reach an optimum for consumption after a period of cold conditioning associated in part to the cell wall metabolism (CHITARRA; CHITARRA, 2005). The soluble solids contents rises slightly during ripening and intensifies a decline in the course of senescence. Optimum values for soluble solids of pears are in the range of $11.0^{\circ}$ Brix (VANGDAL, 1982).
A significant decrease in titratable acidity was observed in control fruit and in fruit submitted to drops onto rubber padding from 6.5 and $15.0 \mathrm{~cm}$ heights. Drops onto a metal surface did not result in changes of titratable acidity (Figure 5). Reductions in acidity were also determined on 'Royal Gala' apples submitted to drops from a $20 \mathrm{~cm}$ height and maintained under refrigerated storage (HENDGES et al., 2011).

Figure 5. Titratable acidity of 'Packham's Triumph' pears submitted to different impacts after storage at $0 \pm 0.5^{\circ} \mathrm{C}$ and $90 \pm 5 \%$ UR for up to 120 days followed by five more days at room temperature $\left(24 \pm 2{ }^{\circ} \mathrm{C}\right)$.

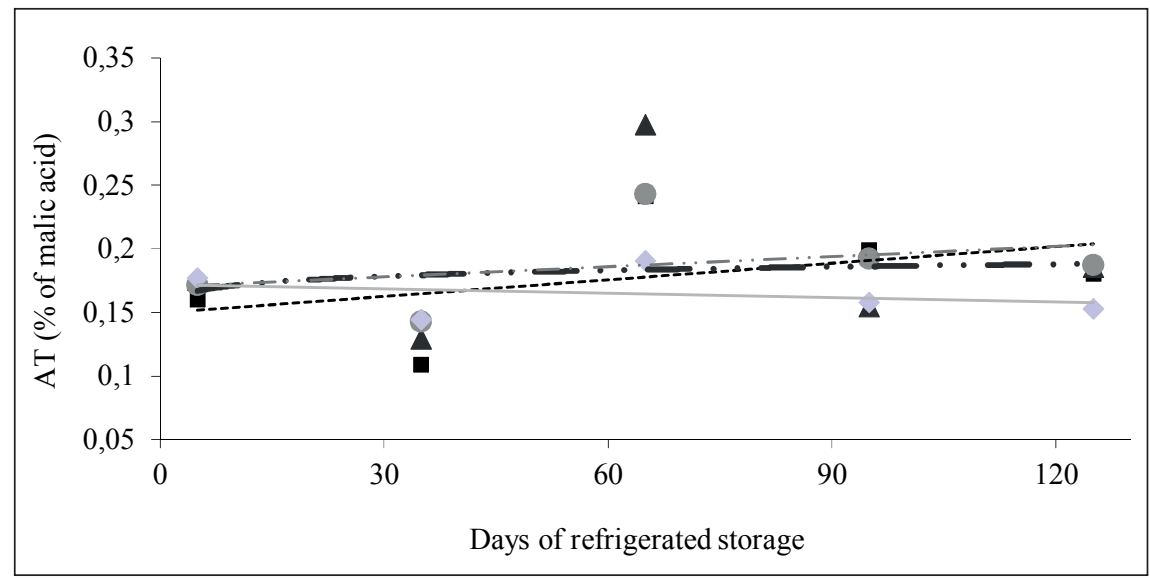

- Control ---- Control: $y=-0,02 x+0,2425^{*} \mathrm{R}^{2}=0,99$

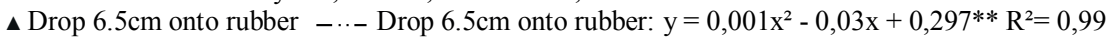

Drop $6.5 \mathrm{~cm}$ onto metal surface — Drop $6.5 \mathrm{~cm}$ onto metal surface: $\mathrm{ns}^{2}=0,99$

- Drop $15 \mathrm{~cm}$ onto rubber - - - Drop $15 \mathrm{~cm}$ onto rubber: $\mathrm{y}=-0,015 \mathrm{x}+0,235^{*} \mathrm{R}^{2}=0,99$

$* \mathrm{p}<0.01 ; * * \mathrm{p}<0.05 ; \mathrm{ns}-$ non significant. 
Immediately after the mechanical injury, the conductivity of the tissues in mannitol solution, which had undergone drops from $15.0 \mathrm{~cm}$ onto a rubber padding or from a $6.5 \mathrm{~cm}$ height onto metallic surface was significantly higher in comparison to the conductivity of the tissues from the other treatments (Figure 6). The leading responses to mechanical injuries of fruit tissues are the prompt modifications on membrane permeability (KAYS, 1991). The conductivity determined after three hours of the mechanical damage is linked to the discharge of ions into the mannitol solution in response to cellular decompartmentalization caused by the injury. The percentage of electrolyte leakage, however, was not different amongst treatments (Figure 6). This result diverges from other authors that determined a boost in electrolyte leakage in pears after submitting the fruit to vibration forces (ZHOU et al., 2007). A significant increase in electrolyte leakage after impact and compression treatments was observed on apples (MONTERO, 2010).

Figure 6. Conductivity (micro S $\mathrm{cm}^{-1}$ ) of tissues in manitol solution at time zero and percentage of electrolyte leakage of 'Packham's Triumph' pears submitted to different impact treatments. Averages followed by the same letter are not significantly different by Tukey test $(p<0.05)$.

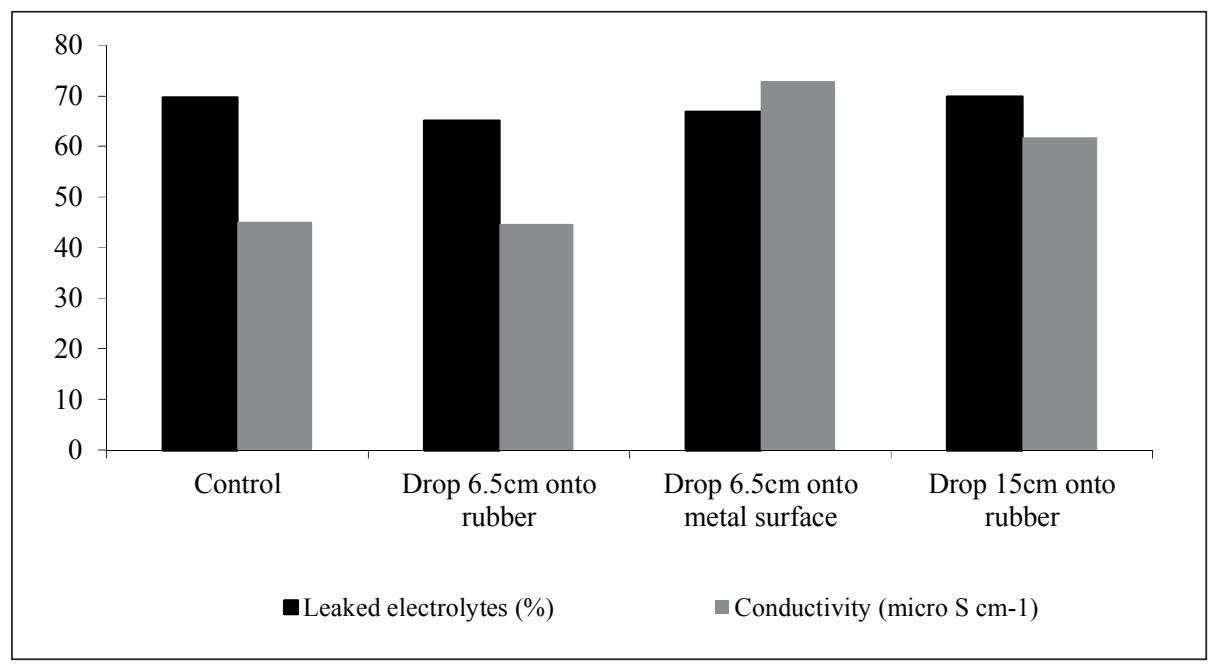

Concerning epidermal color of the pears at the end of each storage period, peel luminosity, as expressed by the $L^{*}$ values, of both injured and healthy tissues presented slight increases (Figure 7).

Healthy areas showed higher $\mathrm{L}^{*}$ values than the injured areas after 120 days: 64.5 e 63.8, respectively. After the room temperature keeping, luminosity of both tissues was similar: 59.5 and 59.0. These results differ from guavas (MATTIUZ; DURIGAN, 2001), apples (MONTERO, 2010) and avocados (SANCHES et al., 2008). Those authors observed that mechanical injuries result in a significant reduction of luminosity of the injured area.

The results of the present study might be attributed to a whitening observed in the mesocarp of the injured areas. A paling of minimally processed carrots was noticed in response to wounds, tissues synthesize a series of intermediary compounds, several of them related to defense mechanisms or to wound healing (LANA, 2000). The compound involved is dependent on the species and nature of the tissue. Increases in $\mathrm{L}^{*}$ values of both healthy and injured tissues might be attributed to ripening as already showed in tests on 'Carrick' pears (COUTINHO et al., 2003).

Fresh weight losses of the 'Packham's Triumph' pears were not correlated to the interaction of storage time and the applied treatments. The losses of weight were linear both at retrieval and after transfer to room temperature (Figure 8). 
Figure 7. Luminosity of healthy (A) and injured peel tissues (B) of 'Packham's Triumph' pears submitted to different impact treatments after cold storage at $0 \pm 0.5{ }^{\circ} \mathrm{C}$ and $90 \pm 5 \%$ UR up to 120 days followed by five more days at room temperature $\left(24 \pm 2{ }^{\circ} \mathrm{C}\right)$. Solid lines: after retrieval from cold storage; dotted lines: after five more days at room temperature.
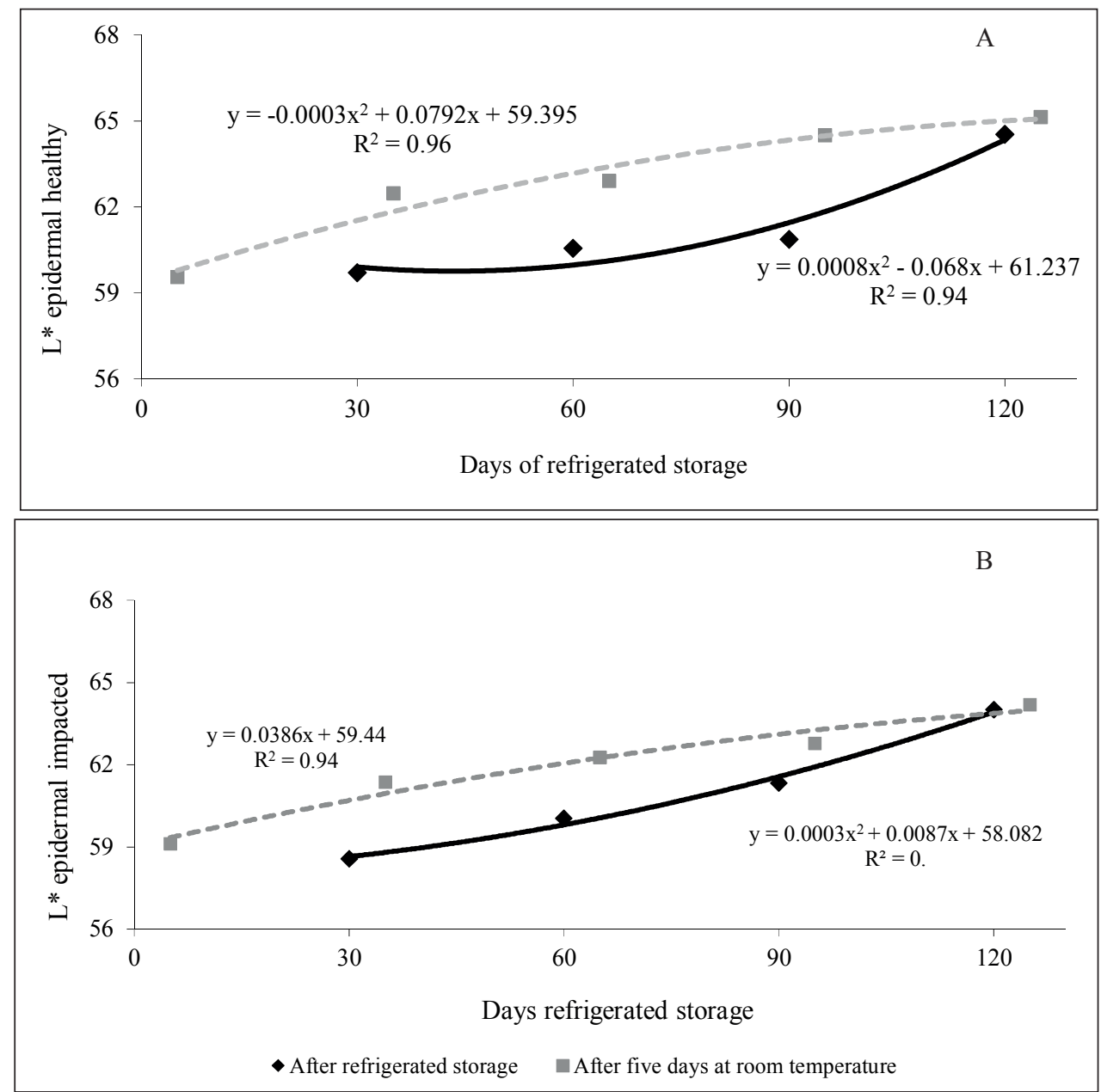

Figure 8. Fresh weight losses (\%) of 'Packham's Triumph' pears submitted to different impact treatments after storage at $0 \pm 0.5^{\circ} \mathrm{C}$ and $90 \pm 5 \%$ UR for up to 120 days followed by five more days at room temperature $\left(24 \pm 2{ }^{\circ} \mathrm{C}\right)$. Solid line: after retrieval from cold storage, dotted lines: after five days at room temperature.

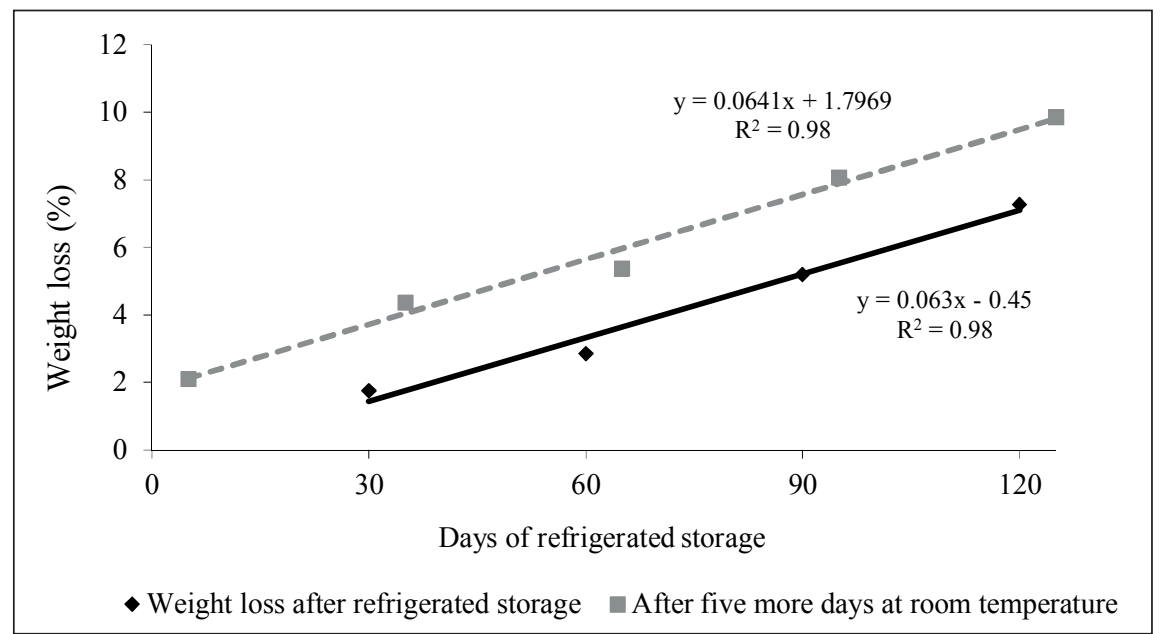


Fresh weight losses increased in all treatments along fruit ripening. However, the losses were more pronounced after the transfer to room temperature. Fresh weight losses are higher the higher the ambient temperature and low relative humidity (HARDENBURG et al., 1986). After 120 days of storage weight losses had reached $9.9 \%$.

The critical points on a commercial packing line defined were: at the transfer from the conveyor belt to the lifting rollers, at the transfer from the lifting rollers to the washing ramp with rotatory brushes, at the entrance to the singulator at the end of the conveyor belt and at the drop from the sizer to the packing stalls. 'Packham's Triumph' pears after $15 \mathrm{~cm}$ impacts onto rubbery paddings do conclude unhindered ripening processes and the injuries do not affect fruit quality even after 120 days of cold storage followed by five days at room temperature.

\section{Acknowledgements}

To the Coordenação de Aperfeiçoamento de Pessoal de Nível Superior (Capes) for the scholarship and to the Empresa Brasileira de Pesquisa Agropecuária (Embrapa) for the project funding (Projeto SEG 03.10.01.032.00.00).

\section{References}

AGAR, I. T.; MITCHAM, E. J. Commercial handling influences quality and ripening of Bartlett Pears. California Agriculture, Oakland, v. 54, n. 3, p. 34-37, 2000.

ANTONIOLLI, L. R.; FERREIRA, M. D. Sistema de avaliação de dano mecânico por impacto em linhas de beneficiamento de maçãs. Bento Gonçalves: Embrapa Uva e Vinho, 2010. (Embrapa Uva e Vinho. Comunicado técnico, 105).

ANTONIOLLI, L. R.; FIALHO, F. B.; FERREIRA, M. D.; SCHAKER, P. C.; HENDGES, M. V.; LERIN, J.; MORO, L. Evaluation of potential mechanical damage in apple packing lines in the main producing regions of Brazil. In: FRUIT, NUT AND VEGETABLE PRODUCTION ENGINEERING SYMPOSIUM, 8., 2009, Concepción. Proceedings... Chillán: Propag -
INIA'S National Precision Agriculture Program, 2009. p. 704-711.

ASSOCIATION OF OFFICIAL ANALYTICAL CHEMISTS - AOAC. Official methods of analysis of AOAC International. 17 $7^{\text {th }}$ Washington: AOAC, 2002.

BROWN, G. K.; SCHULTE-PASON, N. L.; TIMM, E. J. Impact classification using the instrumented sphere. St. Joseph, MI: ASAE, 1990. (ASAE Paper n. 90-6001).

CHITARRA, M. I. F.; CHITARRA, A. B. Pós-colheita de frutas e hortaliças: fisiologia e manuseio. 2. ed. Lavras: UFLA, 2005. 783 p.

COUTINHO, E. F.; MARGARIM, M. B.; SOUZA, E. L.; TREPTOW, R. O. Qualidade pós-colheita da pêra (Pyrus communis L.) cultivar Carrick submetida a diferentes condições de armazenamento. Revista Brasileira de Fruticultura, Jaboticabal, v. 25, n. 3, p. 417-420, 2003.

FELÍCIO, A. H.; JOMORI, M. L. L.; LIMA, G. P. P.; BERNUSSI, A. A. V.; ALVES, R. M.; SASAKI, F. F.; KLUGE, R. A.; JACOMINO, A. P. C. Condicionamento térmico e fungicida na conservação refrigerada de tangor 'Murcott'. Revista Brasileira de Agrociência, Pelotas, v. 12, n. 3, p. 333-339, 2006.

FERREIRA, M. D.; CORTEZ, L. A. B.; HONÓRIO, S. L.; TAVARES, M. Avaliação física do tomate de mesa 'Romana' durante manuseio na pós-colheita. Engenharia Agrícola, Jaboticabal, v. 26, n. 1, p. 321-327, 2006a.

FERREIRA, M. D.; SILVA, M. C.; CAMARGO, G. G. T.; AMORIN, L.; FISHER, I. H. Pontos críticos de impacto em linhas de beneficiamento utilizadas para citros no estado de São Paulo. Revista Brasileira de Fruticultura, Jaboticabal, v. 28, n. 3, p. 523-525, 2006 b.

FIORAVANÇO, J. C.; OLIVEIRA, P. R. D. Produção e importação brasileira de pera no período de 2001 a 2012. Informações Econômicas, São Paulo, v. 44, n. 6, p. 1622, 2014.

GOMILLA, T. Daño por golpe em manzanas em líneas de empaque. Fruticultura e Diversificación, Alto Valle, n. 54, p. 42-48, 2007.

HARDENBURG, R. E.; WANG, C. Y.; WATADA, A. E. The commercial storage of fruits, vegetables, and florist and nursery stocks. Washington: USDA, 1986. 130 p. (USDA. Agriculture Handbook, 66).

HENDGES, M. V.; STEFFENS, C. A.; ANTONIOLLI, L. R.; AMARANTE, C. V. T. do; ZANARDI, O. Z. Qualidade de maçãs 'Fuji suprema' submetidas a diferentes tipos de dano mecânico. Revista Brasileira de Fruticultura, Jaboticabal, v. 33, n. 2, p. 671-675, 2011. 
KAPPEL, F.; FISHER-FLEMING, R.; HOGUE, E. J. Ideal pear sensory attributes and fruit. HortScience, Alexandria, v. 30, n. 5, p. 988-993, 1995.

KAYS, S. J. Postharvest physiology of perishable plant products. New York: Van Noshard Reinhold, 1991. 532 p.

LANA, M. M. Aspectos da fisiologia de cenoura minimamente processada. Horticultura Brasileira, Brasília, v. 18, n. 3, p. 154-158, 2000.

MAGALHÃES, A. M.; FERREIRA, M. D. Qualidade dos frutos de tomate de mesa quando submetidos a impacto por ocasião do beneficiamento. Horticultura Brasileira, Brasília, v. 24, n. 4, p. 481-484, 2006.

MAGALHÃES, A. M.; FERREIRA, M. D.; BRAUNBECK, O. A.; ESTEVOM, M. V. R. Superfícies protetoras na diminuição de danos mecânicos em tomate de mesa. Ciência Rural, Santa Maria, v. 37, n. 3, p. 878881, 2007.

MATTIUZ, B.; DURIGAN, J. F. Efeito de injúrias mecânicas na firmeza e coloração de goiabas das cultivares Paluma e Pedro Sato. Revista Brasileira de Fruticultura, Jaboticabal, v. 23, n. 2, p. 277-281, 2001.

MILLER, W. M.; WAGNER, C. Florida citrus packing line studies with an instrumented sphere. Applied Engineering in Agriculture, St. Joseph, v. 7, n. 5, p. 577581, 1991.

MONTERO, C. R. S. Alterações fisiológicas e anatômicas causadas por danos mecânicos durante o beneficiamento de maçãs e frutos cítricos. 2010. Tese (Doutorado em Fitotecnia) - Programa de Pós-Graduação em Fitotecnia, Faculdade de Agronomia, Universidade Federal do Rio Grande do Sul, Porto Alegre.
MORETTI, C. L. Manual de processamento mínimo de frutas e hortaliças. Brasília: SEBRAE, 2007.

SANCHES, J., DURIGAN, J. F.; DURIGAN, M. F. B. Aplicação de danos mecânicos em abacates e seus efeitos na qualidade dos frutos. Engenharia Agrícola, Jaboticabal, v. 28, n. 1, p.164-175, 2008.

SEGATORI, A. (Coord.). Daño por golpes. Proyecto Nacional ${ }^{\circ} 52-535$. Alto Valle Del Rio Negro: INTA Alto Valle, 2006. Disponível em: $<$ http:// www.biblioteca.org. ar/libros/210424.pdf>. Acesso em: 03 dez. 2014.

SINOBAS, L. R.; RUIZ-ALTISENT, M.; PEREZ, J. Bruise development and fruit response of pear (cv. 'Blanquilla') under impact conditions. Journal of Food Engineering, London, v. 14, n. 4, p. 289-301, 1991.

STEFFENS, C. A.; ESPÍNDOLA, B. P.; AMARANTE, C. V. T.; SILVEIRA, J. P. G.; CHECHI, R.; BRACKMANN, A. Respiração, produção de etileno e qualidade de maçãs 'Gala' submetidas ao dano mecânico e tratadas com 1-metilciclopropeno. Ciência Rural, Santa Maria, v. 38, n. 7, p. 1864-1870, 2008.

VANGDAL, E. Eating quality of pears. Acta Agriculture Scandinavica, Norway, v. 32, n. 2, p. 135-139, 1982.

ZHOU, R. SU, S.; YAN, L.; LI, Y. Effect of transport vibration levels on mechanical damage and physiological responses of 'Huanghua' pears (Pyrus pyrifolia Nakai, cv. Huanghua). Postharvest Biology and Technology, Amsterdam, v. 46, n. 1, p. 20-28, 2007. 